\title{
Cardio classics revisited - focus on the role of candesartan
}

\author{
This article was published in the following Dove Press journal: \\ Vascular Health and Risk Management \\ 23 November 2010 \\ Number of times this article has been viewed
}

\section{Maria Leonarda De Rosa \\ University of Naples Federico II, Department of Cardiology, Naples, Italy}

Correspondence: Professor Maria Leonarda De Rosa

University of Naples, Department of Cardiology,

Via Caravaggio 3080126

Naples, Italy

Email marialeonarda.derosa@unina.it
Abstract: Angiotensin II receptor blockers (ARBs) are antihypertensive agents with considerable evidence of efficacy and safety for the reduction of cardiovascular (CV) disease risk in numerous patient populations across the $\mathrm{CV}$ continuum. There are several agents within this class, all of which have contributed to various degrees, to this evidence base. The evidence with ARBs continues to accumulate, with ongoing trials investigating their role in additional patient populations, potentially expanding their efficacy across a broad spectrum of CV disease states. Cardiovascular disease (CVD) is a leading cause of death around the world, accounting for approximately $29.2 \%$ of total global deaths. Of all the deaths attributed to CVD, approximately $43 \%$ are due to ischemic heart disease, $33 \%$ to cerebrovascular disease, and $23 \%$ to hypertensive and other heart conditions. CVD has been represented as a "CV continuum". This continuum concept can be used to describe CVD in general or in specific vascular beds (eg, coronary artery disease or cerebrovascular disease). This review article will discuss the results of the landmark ARB candesartan clinical trials published over the past decade. The evidence presented spans the entire CV continuum, including the effects of ARBs in at-risk patients, stroke, myocardial infarction (MI), and heart failure (HF), as well as a brief discussion of ongoing trials.

Keywords: candesartan, cardiovascular disease, angiotensin II receptor blockers

\section{Angiotensin II receptor blockers (ARBs) for cardioprotection in at-risk patients}

There have been several large comparative clinical trials examining the impact of ARB therapy on cardiovascular (CV) morbidity and mortality in at-risk patients (Table 1).

In the LIFE study, the difference in the composite endpoint was largely driven by a significant difference in stroke between the two groups ( $25 \%$ relative risk reduction [RRR]; adjusted hazard ratio [HR] 0.75, 95\% confidence interval [CI]: 0.63-0.89; $P=0.001)^{1}$ (Figure 2).

In SCOPE, there was a statistically significant mean difference between the treatment groups in adjusted blood pressure (BP) reduction: $3.2 / 1.6 \mathrm{mmHg}$ in favor of the candesartan group $(P<0.001)$. While no statistically significant risk reduction for the primary endpoint was observed (RRR: $10.9 \%$; 95\% CI: $-6.0-25.1, P=0.19$ ), a significant $27.8 \%$ RRR for nonfatal stroke $(P=0.04)$ and nonsignificant $23.6 \%$ RRR in all stroke $(P=0.056)$ in favor of candesartan were reported. ${ }^{2}$

In the VALUE trial, BP was significantly lower with amlodipine after 1 month $(4.0 / 2.1 \mathrm{mmHg}$ difference compared to valsartan, $P<0.001)$ and after 1 year $(1.5 / 1.3 \mathrm{mmHg}$ difference compared to valsartan; $P<0.001))^{3-5}$ submit your manuscript $\mid$ www.dovepress.com

Dovepress

DOI: 10.2147/VHRM.S9433 


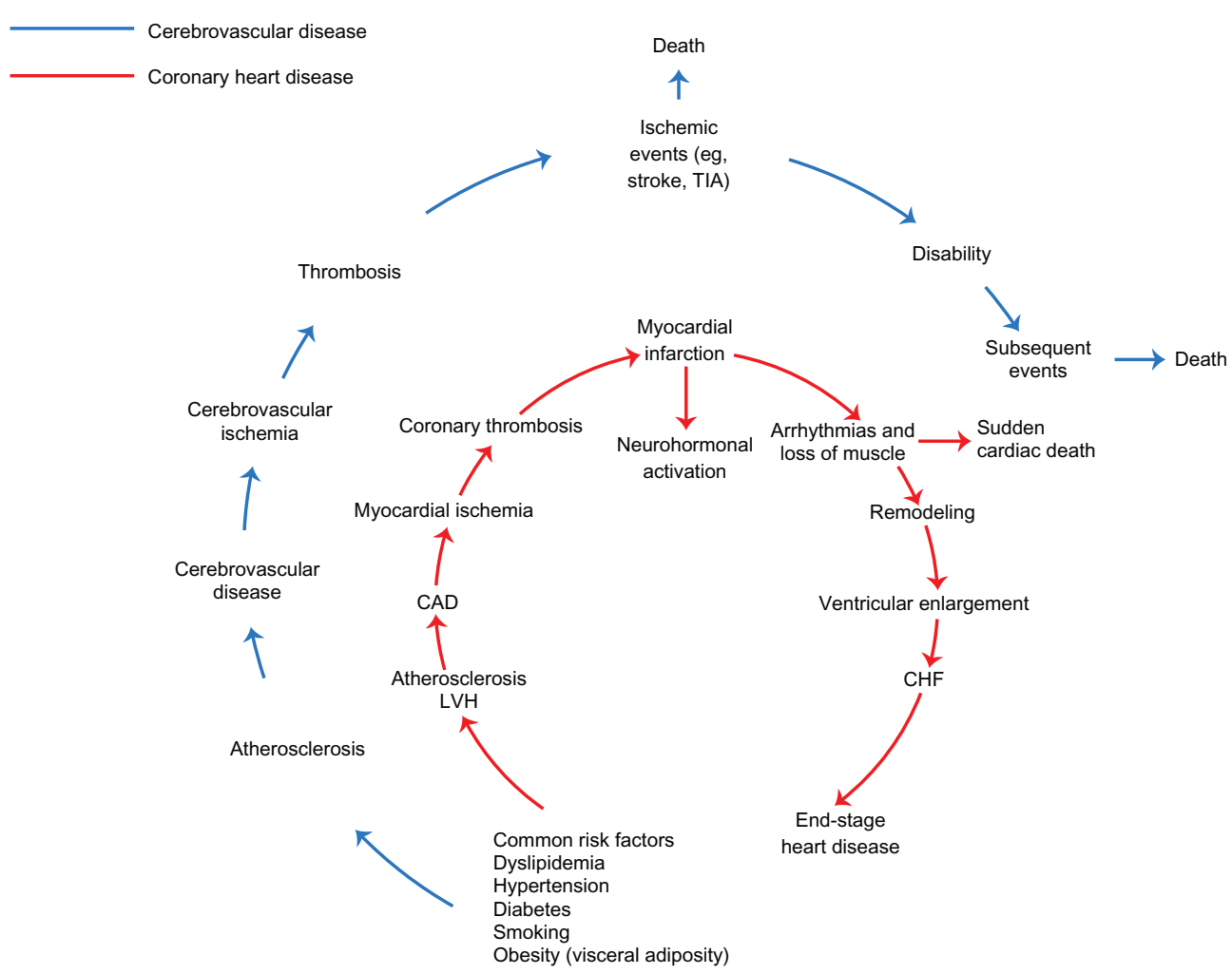

Figure I The CV continuum. Copyright (C) 2004, Elsevier. Adapted with permission from Julius S, Kjeldsen SE, Weber M, et al; VALUE trial group. Outcomes in hypertensive patients at high cardiovascular risk treated with regimens based on valsartan or amlodipine: the VALUE randomised trial. Lancet. 2004;363(9426):2022-203I.

Abbreviations: $\mathrm{LVH}$, left-ventricular hypertrophy; CAD, coronary artery disease; CHF, congestive heart failure; TIA, transient ischemic attack.

Valsartan was further evaluated in the JIKEI-HEART study, the incidence of the composite endpoint was $6.0 \%$ in the valsartan group and $9.7 \%$ in the non-ARB group, for a RRR of $39 \%$ with valsartan (HR 0.61, 95\% CI: 0.47-0.79, $P=0.0002)^{6,7}$ (Figure 3).

Most recently, two large, parallel studies evaluating the cardioprotective effects of telmisartan have been published: ONTARGET and TRANSCEND trials. ${ }^{8,9}$

ONTARGET demonstrated that telmisartan was noninferior to ramipril, with no significant difference in the proportion of patients experiencing the primary endpoint (relative risk [RR] 1.01; 95\% CI: 0.94-1.09; Figure 4). InTRANSCEND study in the secondary composite endpoint of CV death, mycardial infarction (MI) and stroke, telmisartan therapy was associated with a $13 \%$ RRR compared to placebo (HR 0.87, 95\% CI: $0.76-1.00, P=0.048$ unadjusted. ${ }^{9}$

\section{Effect of ARBs on specific conditions along the CV continuum}

The following section documents the efficacy data for ARBs in studies examining more specific patient populations, including those with more advanced disease (eg, post-MI, stroke, and heart failure; Table 1).

\section{Post-stroke}

Clinical trial data support the ability of ARBs to prevent stroke in various populations.

In the MOSES study, the reduction in subsequent cerebrovascular events also favored eprosartan (IDR 0.75; $95 \%$ CI: $0.58-0.97 ; P=0.03)$. BP was similar in both treatment arms at the end of the study. ${ }^{10}$

In the PRoFESS study, $8.7 \%$ of patients in the telmisartan group and $9.2 \%$ of those in the placebo group had a recurrent stroke (the primary endpoint). However, the between-group difference was not statistically significant (HR 0.95; 95\% CI: $0.86-1.04 ; P=0.23) .{ }^{11}$

\section{Myocardial ischemia and infarction}

In the OPTIMAAL study, the investigators reported no significant difference in the primary endpoint between the treatment groups. But it remains unknown whether losartan is noninferior to captopril in this patient population. ${ }^{12}$

In the VALIANT study, in the primary endpoint analysis (all-cause mortality), valsartan met a priori defined criteria for non-inferiority compared to captopril (HR 1.00; 97.5\% CI: $0.90-1.11 ; P=0.98$ ) (Figure 5$).{ }^{13}$ The VALIANT investigators also included an imputed placebo analysis designed to 


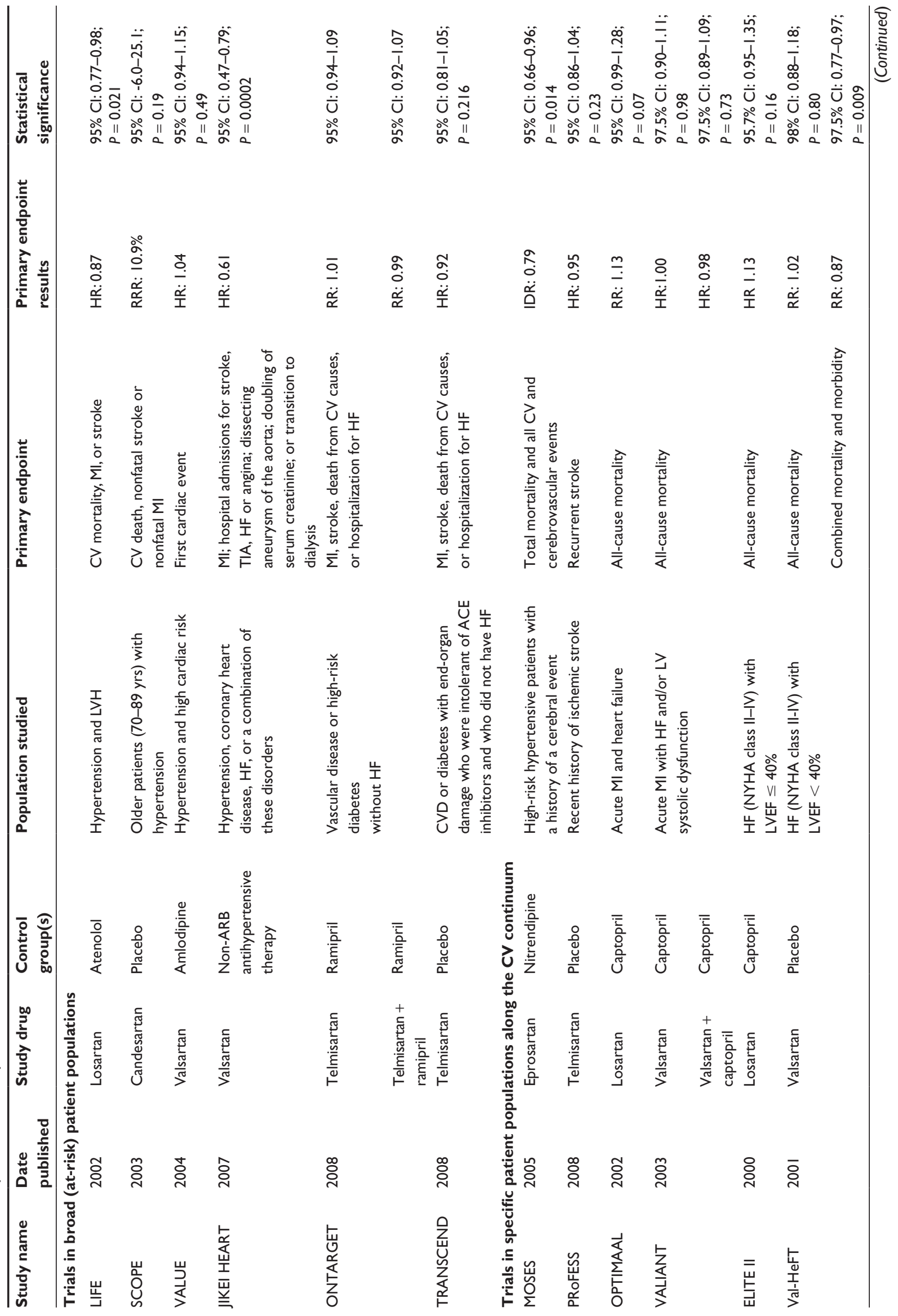




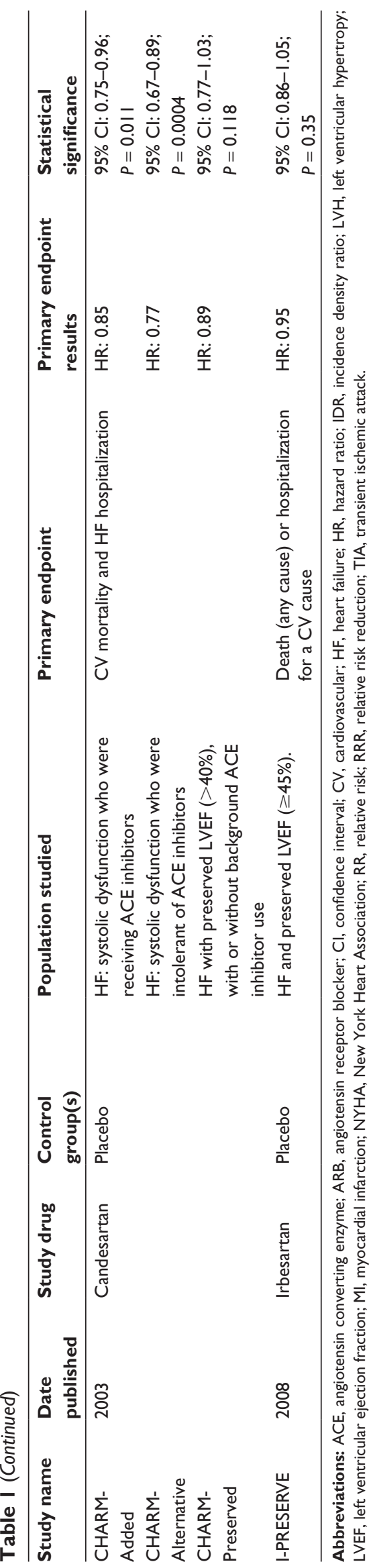

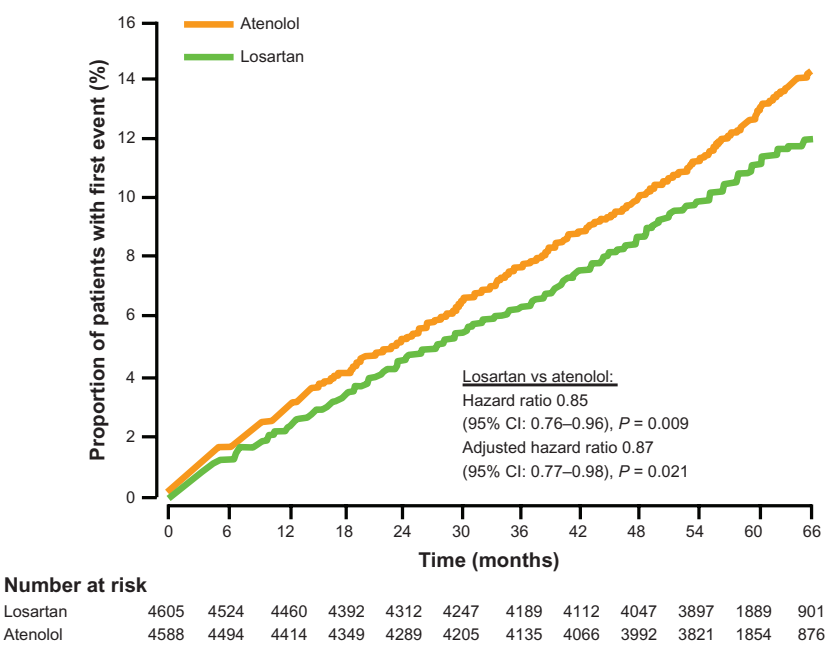

Figure 2 Kaplan-Meier curves for the primary composite endpoint in the life study: losartan vs atenolol in patients with hypertension and LVH. Copyright (C) 2002, Elsevier. Adapted with permission from Dahlöf B, Devereux RB, Kjeldsen SE, et al. Cardiovascular morbidity and mortality in the Losartan Intervention For Endpoint reduction in hypertension study (LIFE): a randomised trial against atenolol. Lancet. 2002;359(931I):995-1003.

Abbreviation: $\mathrm{Cl}$, confidence interval.

evaluate their findings in the context of the placebo-controlled results of the Survival and Ventricular Enlargement (SAVE) trial, which evaluated captopril, ${ }^{14}$ and two other similarly designed ACE inhibitor trials, which tested ramipril and trandolapril in the post-MI setting (the Acute Infarction Ramipril Efficacy [AIRE] trial and the Trandolapril Cardiac Evaluation [TRACE] trial, respectively). ${ }^{15,16}$ The two monotherapies were also found to have equivalent effects on other major $\mathrm{CV}$ endpoints (eg, MI, stroke). ${ }^{17}$

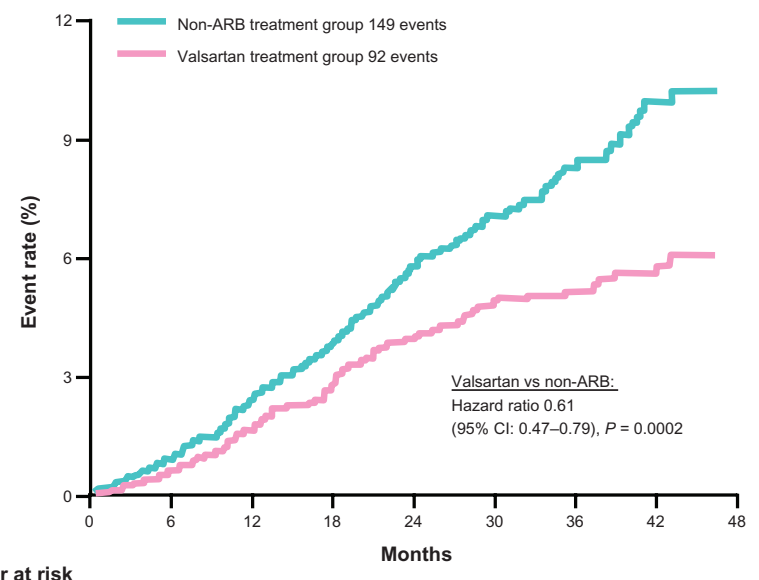

Number at risk

$\begin{array}{llllllllll}\text { Valsartan group } & 1541 & 1504 & 1441 & 1257 & 1092 & 855 & 689 & 368 & 368 \\ & 1540 & 1502 & 1447 & 1262 & 1075 & 835 & 657 & 344 & 343\end{array}$

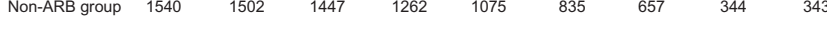

Figure 3 Kaplan-Meier curves of the cumulative frequency of the combined primary endpoint (cv morbidity and mortality) in the jikei heart study: valsartan vs non-ARB treatment. Copyright (C) 2007, Elsevier. Adapted with permission from Mochizuki S, Dahlöf B, Shimizu M, et al. Valsartan in a Japanese population with hypertension and other cardiovascular disease (likei Heart Study): a randomised, open-label, blinded endpoint morbidity-mortality study. Lancet. 2007;369(957I):|43I-I439.

Abbreviations: ARB, angiotensin II receptor blocker; $\mathrm{Cl}$, confidence interval, 


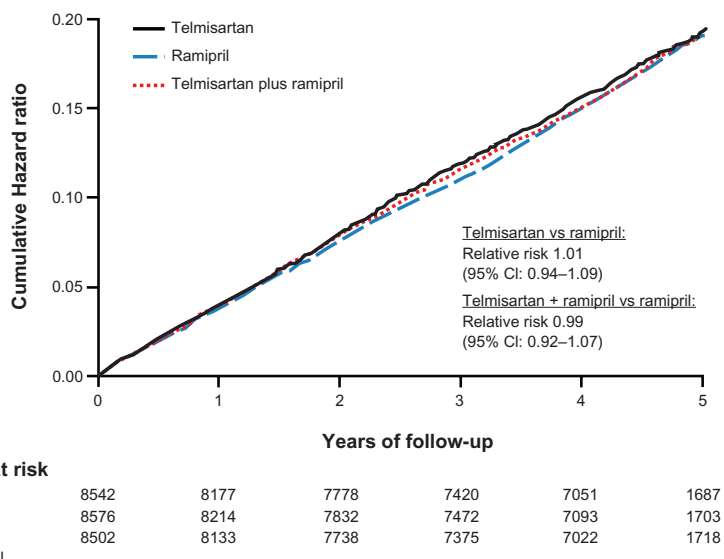

$\begin{array}{lllllll}\text { Number at risk } & & & & 7420 & 7051 & 1687 \\ \text { Telmisartan } & 8542 & 8177 & 7778 & 7420 & 7093 & 1703 \\ \text { Ramipril } & 8576 & 8214 & 7832 & 7472 & 7022 & 1718\end{array}$ Telmisartan plus ramipri

Figure 4 Kaplan-Meier curves for the primary outcome (death from CV causes, MI, Stroke, or hospitalization for HF) in ONTARGET. Copyright (C 2008, Massachusetts Medical Society. Adapted with permission from ONTARGET Investigators, Yusuf S, Teo KK, et al. Telmisartan, ramipril, or both in patients at high risk for vascular events. N Engl J Med. 2008;358(I5):1547-1559.

Abbreviations: ONTARGET, Ongoing Telmisartan Alone and in Combination with Ramipril Global Endpoint Trial; Cl, confidence interval.

\section{Heart failure (HF)}

The ELITE II study ${ }^{18}$ sought to validate the findings of ELITE,${ }^{19}$ a study in which low-dose losartan was unexpectedly found to be superior to captopril for the reduction of mortality in patients with HF (a secondary endpoint of ELITE). This trial was designed as a superiority study and was not designed to show equivalence; thus, whether or not an $\mathrm{ARB}$ is as protective as an ACE inhibitor in HF remained unanswered by ELITE II.

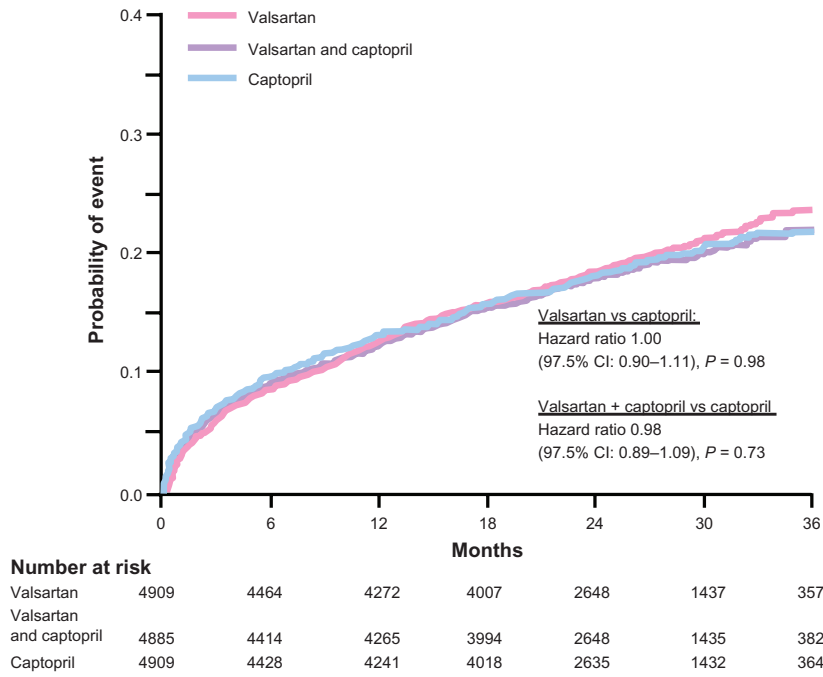

Figure 5 Kaplan-Meier estimates of the rate of death from any cause in the VALIANT Study: valsartan, captopril or their combination in Post-MI patients. Copyright (C) 2003, Massachusetts Medical Society. Adapted with permission from Pfeffer MA, McMurray JJ, Velazquez EJ, et al.Valsartan, captopril, or both in myocardial infarction complicated by heart failure, left ventricular dysfunction, or both. $N$ Engl J Med. 2003;349(20): I893-1906.

Abbreviations: VALIANT, Valsartan in Acute Myocardial Infarction; $\mathrm{Cl}$, confidence interval.
In the Val-HeFT study, there was no significant difference in all-cause mortality between the two treatment arms (RR 1.02; $98 \%$ CI: $0.88-1.18 ; P=0.80){ }^{20}$

The Candesartan in Heart failure Assessment of Reduction in Mortality and Morbidity (CHARM) study program ${ }^{21}$ consisted of a series of separate randomized, controlled studies designed to investigate the benefits of candesartan in three distinct populations of patients with symptomatic HF: those with systolic dysfunction who were receiving ACE inhibitors (CHARM-Added, $\mathrm{n}=2,548$ ), ${ }^{22}$ those with systolic dysfunction who were intolerant of ACE inhibitors (CHARM-Alternative, $\mathrm{n}=2,028)^{23}$ and those with preserved left ventricular (LV) systolic function with or without background ACE inhibitor use (CHARMPreserved, $n=3,023) .{ }^{24}$ The primary objective in each trial was to evaluate the effects of candesartan on the combined primary endpoint of $\mathrm{CV}$ mortality or congestive heart failure (CHF) hospitalization.

After a median follow up of 41 months in the CHARMAdded trial, $38 \%$ of those in the candesartan group experienced a primary event compared to $42 \%$ in the placebo group. ${ }^{22}$ The RRR for candesartan (on top of the benefit the patients were already receiving from ACE inhibition) was $15 \%$ compared to placebo (unadjusted HR $0.85 ; 95 \%$ CI: $0.75-0.96 ; P=0.011)$. The results for each of the components of the primary endpoint were also significantly in favor of candesartan; the RRR was $16 \%$ for CV death (unadjusted HR 0.84; 95\% CI: $0.72-0.98 ; P=0.029$ ) and

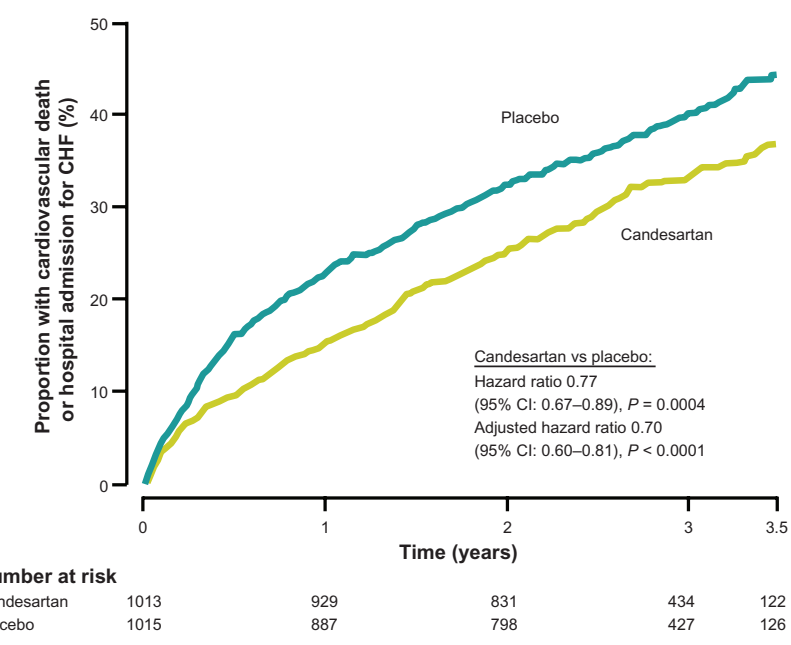

Figure 6 Kaplan-Meier Cumulative Event Curves for the Combined Primary Endpoint (CV Morality + Hospitalization for Heart Failure): Candesartan vs Placebo in ACE-inhibitor-intolerant Patients - CHARM-alternative. Copyright $@$ 2003, Elsevier. Adapted with permission from Granger CB, McMurray JJ, Yusuf S, et al. Effects of candesartan in patients with chronic heart failure and reduced left-ventricular systolic function intolerant to angiotensin-converting-enzyme inhibitors: the CHARMAlternative trial. Lancet. 2003;362(9386):772-776.

Abbreviations: CHARM, Candesartan in Heart failure Assessment of Reduction in Mortality and Morbidity; $\mathrm{CHF}$, congestive heart failure; $\mathrm{Cl}$, confidence interval. 
$17 \%$ for $\mathrm{HF}$ hospitalization (unadjusted HR $0.83 ; 95 \%$ CI: $0.71-0.96 ; P=0.014)$. This study further supports the concept introduced by Val-HeFT that adding an ARB to ACE inhibition may provide benefit in patients with $\mathrm{HF}$ and systolic dysfunction.

Over a median follow up of 33.7 months in the CHARM-Alternative trial, the RRR for the primary composite outcome was $23 \%$ in favor of candesartan (unadjusted HR 0.77; 95\% CI: $0.67-0.89 ; P=0.0004$; Figure 6). ${ }^{23}$ This finding appears to have been driven primarily by a reduction in HF hospitalizations, for which the RRR was $32 \%$ (unadjusted HR 0.68; 95\% CI: $0.57-0.81$; $P<0.0001)$.

In the CHARM-Preserved study, there was no significant difference in the primary endpoint between the two treatment arms over a median follow up of 36.6 months (unadjusted HR 0.89; 95\% CI: $0.77-1.03 ; P=0.118) .{ }^{24}$

In I-PRESERVE, there was no significant difference in the primary composite outcome between irbesartan and placebo (HR 0.95; 95\% CI: 0.86-1.05; $P=0.35) .{ }^{25}$

Although ARBs have been shown to be effective for treating patients with established HF, they have not shown such an effect in its prevention. ${ }^{26}$

\section{Ongoing ARB studies}

Clinical trials have clearly demonstrated the efficacy of ARBs throughout the CV continuum. Additionally, studies are ongoing investigating the utility of ARBs in several patient populations in which the efficacy of ARBs is currently unknown or inadequately investigated. ${ }^{27-35}$

Table 2 Ongoing ARB trials with primary CV endpoints across the CV continuum

\begin{tabular}{|c|c|c|c|c|c|}
\hline Study name & ARB & Study population & n (approx.) & Primary endpoint(s) & Novelties \\
\hline ACTIVE-I ${ }^{27}$ & Irbesartan & $\begin{array}{l}\text { Atrial fibrillation and } \geq I \text { risk } \\
\text { factor for stroke }\end{array}$ & 9,000 & $\begin{array}{l}\text { Composite of CV events (stroke, non-CNS } \\
\text { systemic embolism, MI, or vascular death) }\end{array}$ & \\
\hline $\mathrm{CORAL}^{28}$ & Candesartan & Renal artery stenosis & 1,080 & $\begin{array}{l}\text { Composite } \mathrm{CV} \text { and renal endpoint: } \mathrm{CV} \text { or } \\
\text { renal death, } \mathrm{MI} \text {, hospitalization for } \mathrm{CHF} \text {, } \\
\text { stroke, doubling of serum creatinine, and } \\
\text { need for renal replacement therapy }\end{array}$ & \\
\hline KYOTO HEART ${ }^{29}$ & Valsartan & High-risk hypertension & 3,000 & $\begin{array}{l}\text { Composite of CV/renal events (stroke, TIA, } \\
\text { MI, HF, angina, dissecting aortic aneurysm, } \\
\text { lower limb arterial obstruction, emergency } \\
\text { thrombosis, transition to dialysis or } \\
\text { doubling of serum creatinine) }\end{array}$ & \\
\hline NAGOYA HEART ${ }^{30}$ & Valsartan & $\begin{array}{l}\text { Hypertension with diabetes } \\
\text { or impaired glucose tolerance }\end{array}$ & 3,000 & $\begin{array}{l}\text { Fatal or nonfatal MI, fatal or nonfatal } \\
\text { stroke, admission due to CHF, coronary } \\
\text { revascularization, sudden cardiac death }\end{array}$ & \\
\hline NAVIGATOR ${ }^{31}$ & Valsartan & Impaired fasting glucose & 9,518 & $\begin{array}{l}\text { Progression to diabetes; extended CV } \\
\text { composite (CV death, nonfatal MI, } \\
\text { nonfatal stroke, hospitalization for HF, } \\
\text { revascularization or hospitalization for } \\
\text { unstable angina); core CV composite } \\
\text { (CV death, nonfatal MI, nonfatal stroke, } \\
\text { or hospitalization for HF) }\end{array}$ & \\
\hline ROADMAP $^{32}$ & Olmesartan & $\begin{array}{l}\text { Type } 2 \text { diabetes with } \\
\text { normoalbuminuria }\end{array}$ & 4,400 & $\begin{array}{l}\text { Occurrence of microalbuminuria ( } \mathrm{CV} \\
\text { morbidity and mortality as secondary } \\
\text { endpoint) }\end{array}$ & \\
\hline SCAST $^{33}$ & Candesartan & Acute stroke & 2,500 & $\begin{array}{l}\text { Death or disability at } 6 \text { months; } \\
\text { combination of vascular death, myocardial } \\
\text { infarction, or stroke during the first } \\
6 \text { months }\end{array}$ & \\
\hline VALISH $^{34}$ & Valsartan & Isolated systolic hypertension & 3,000 & $\begin{array}{l}\text { Composite of CV events (sudden death, } \\
\text { fatal or nonfatal stroke, fatal or nonfatal } \\
\text { MI, death due to HF, other CV death, } \\
\text { unplanned hospitalization for CV disease, } \\
\text { and renal disorder) }\end{array}$ & \\
\hline VART ${ }^{35}$ & Valsartan & Hypertension & 797 & CV morbidity and mortality & \\
\hline
\end{tabular}

Abbreviations: ACTIVE-I, atrial fibrillation clopidogrel trial with irbesartan for prevention of vascular events; CORAL, cardiovascular outcomes in renal atherosclerotic lesions; NAGOYA HEART, novel antihypertensive goal of hypertension with diabetes - hypertensive events and ARB treatment; NAVIGATOR, nateglinide and valsartan in impaired glucose tolerance outcomes research; ROADMAP, randomized olmesartan and diabetes microalbuminuria prevention; SCAST, Scandinavian candesartan acute stroke trial; VALISH: valsartan in elderly isolated systolic hypertension; VART, valsartan amlodipine randomized trial; CNS, central nervous system; CV, cardiovascular; MI, myocardial infarction; HF, heart failur; CHF, congestive heart failure; TIA, transient ischemic attack. 
These key ongoing studies are summarized in Table 2, along with their significance in the CV continuum. Additionally, there are newer therapeutic approaches to suppress the RAS system through direct renin inhibition. Currently, a comprehensive clinical trial program known as ASPIRE-HIGHER, is evaluating the effects of the direct renin inhibitor, aliskiren, on various $\mathrm{CV}$ and cardio-renal endpoints. $^{36}$

\section{Role of candesartan: indications for this angiotensin II receptor blocker Binding characteristics of the ATI- receptor blockers at the ATI receptor}

Candesartan cilexetil, is administered in an inactive form and is rapidly and completely converted to the active drug, candesartan, during gastrointestinal absorption. In vitro studies have shown that candesartan has the highest receptor affinity of all the available AT1-receptor blockers and is not displaced from the receptor by high concentrations of angiotensin II. The tight and long-lasting binding of candesartan to the AT1-receptor provides effective blockade of the negative cardiovascular effects of angiotensin II.

Candesartan reduces the maximal response to angiotensin II, and can almost completely abolish the response; this inhibition cannot be overcome by increasing concentrations of angiotensin II and hence is described as insurmountable inhibition. ${ }^{37,38}$ It results from fast and reversible binding of the antagonist to the receptor, whereas fully insurmountable inhibition, as with candesartan, is related to slow dissociation of the receptor-antagonist complex. ${ }^{38}$ In other studies, reversal of the inhibitory effect of candesartan in $\mathrm{CHO}$ cells was slower than with irbesartan or EXP-31748, while the effect of losartan was almost instantaneously reversible, suggesting that insurmountable antagonism is related to prolonged binding of the antagonist to the receptor. ${ }^{39}$

The potent AT1-receptor blockade produced by candesartan and EXP-3174 appears to be related to the presence of two negatively charged groups, a carboxyl group and a tetrazole moiety: the less potent precursors of these molecules, candesartan cilexetil and losartan, possess only the tetrazole moiety. ${ }^{38}$ Other potent AT1-receptor blockers also appear to be diacidic molecules. ${ }^{38}$ Experiments with candesartan analogues suggest that appropriate alignment of the carboxylgroups is a prerequisite for tight and prolonged binding, and hence for insurmountable antagonism. ${ }^{38}$

\section{Tolerability}

The long-term efficacy and tolerability of candesartan cilexetil was assessed in two open-label, prospective multicentered studies in patients with mild to moderate essential hypertension. ${ }^{39}$ Candesartan cilexetil was well tolerated and was devoid of clinically relevant biochemical, hematological or cardiac effects. Only $12 \%$ of adverse events were judged to be causally related to the drug and only about $5 \%$ of patients withdrew from therapy due to adverse events. The most common adverse events were typical of patients with hypertension in general. Most adverse events appeared during the first 3 months of treatment and their incidence decreased steadily with time. Tolerability was unrelated to gender, age ( $<65$ versus $\geq 65$ years) or dosage. These results demonstrate that candesartan cilexetil maintains its antihypertensive effects and tolerability during long-term administration..$^{40}$

Candesartan does not inhibit ACE, also known as kininase II, the enzyme that converts angiotensin I to angiotensin II and degrades bradykinin, nor does it bind to or block other hormone receptors or ion channels known to be important in cardiovascular regulation. It therefore leads to fewer side effects, particularly the troublesome cough with ACE inhibitors.

\section{Clinical indications}

Candesartan is currently licensed for the treatment of hypertension and HF with reduced left ventricular function. However, candesartan may have wider benefits in the treatment of renal disease and diabetic retinopathy.

\section{Hypertension}

Candesartan therapy causes a dose-dependent reduction in arterial blood pressure. Systemic peripheral resistance is decreased, while heart rate, stroke volume and cardiac output are not significantly affected. ${ }^{41}$ No first dose hypotension was observed during controlled clinical trials with candesartan.

Most of the antihypertensive effect develops within 2 weeks of initial dosing, with a full effect seen by 4 weeks. With once-daily dosing, the BP effect was maintained over 24 hours with trough to peak ratios of more than $80 \%$. As once-daily monotherapy, candesartan cilexetil $8 \mathrm{mg}$ is as effective as enalapril 10-20 mg, amlodipine $5 \mathrm{mg}$ or hydrochlorothiazide $25 \mathrm{mg}$, and candesartan cilexetil $16 \mathrm{mg}$ is more effective than losartan $50 \mathrm{mg} .{ }^{42}$

The results of a number of head-to-head clinical comparisons between ARBs suggest that candesartan cilex- 
etil and irbesartan may be more effective than the losartan. ${ }^{43}$ Ambulatory BP studies have clarified the relative duration of antihypertensive action of the AT1 receptor blockers. In particular, studies mimicking the common event of a missed or delayed tablet show that the antihypertensive effect of candesartan cilexetil extends well beyond the $24 \mathrm{~h}$ dosing interval, while the effect of losartan declines rapidly over this period.

Candesartan cilexetil has additional BP lowering effects when added to hydrochlorothiazide. ${ }^{44}$ Candesartan/hydrochlorothiazide (CC/HCTZ) combination and amlodipine were equally effective in reducing BP in patients with hypertension not controlled by monotherapy, but $\mathrm{CC} / \mathrm{HCTZ}$ was better tolerated. ${ }^{45}$ After 8 weeks of treatment both regimens reduced mean trough $\mathrm{BP}$ by similar amounts: mean sitting $\mathrm{SBP} / \mathrm{DBP}$ reductions were $-15.4 /-11.9 \mathrm{mmHg}$ for $\mathrm{CC} / \mathrm{HCTZ}$ and $-15.7 /-12.0 \mathrm{mmHg}$ for amlodipine (group differences, $P=0.835 / 0.963)$. The BP of $84.2 \%$ of patients on $\mathrm{CC} / \mathrm{HCTZ}$ and $84.5 \%$ on amlodipine was controlled (sitting DBP $<90$ $\mathrm{mmHg}$ and sitting SBP $<140 \mathrm{mmHg})(P=1.00)$. Six $(5.9 \%)$ patients on CC/HCTZ and $18(17.6 \%)$ on amlodipine discontinued treatment, including one $(1 \%)$ and $12(11.8 \%)$, respectively, owing to adverse events $(P<0.001)$. The most common adverse event was peripheral edema, which occurred in two patients on $\mathrm{CC} / \mathrm{HCTZ}$ and 19 on amlodipine. Other trials have confirmed the safety and efficacy of $\mathrm{CC} / \mathrm{HCZ}$ combination therapy in the treatment of severe hypertension (DBP > $110 \mathrm{mmHg}){ }^{46,47}$

The tolerability of candesartan was similar in men and women and in patients older and younger than $65 .{ }^{48}$ Candesartan was effective in reducing BP regardless of race, although the effect was slightly lower in black (usually a low-renin population) than in white people. ${ }^{49}$

\section{Hypertension endpoint studies}

While the data on the antihypertensive benefits of candesartan are compelling in terms of efficacy, there are fewer reported hard endpoint clinical trials. The Study on Cognition and Prognosis in the Elderly (SCOPE) enrolled 4964 patients aged 70-89 years. Patients were randomly assigned to double-blind candesartan or placebo with open-label antihypertensive therapy (mostly thiazide diuretics) added as needed to control blood pressure. Approximately $35 \%$ of patients had isolated systolic hypertension (SBP $>60 \mathrm{mmHg}$, DBP $<90 \mathrm{mmHg}$ ). Blood pressure fell by $21.7 / 10.8 \mathrm{mmHg}$ in the candesartan group and by $18.5 / 9.2 \mathrm{mmHg}$ in the control group. Candesartan-based therapy was associated with a nonsignificant $10.9 \%$ relative risk reduction (242 versus 268 events) in the primary composite endpoint of cardiovascular death, nonfatal stroke and nonfatal myocardial infarction. There were significant reductions in nonfatal stroke $(27.8 \%$, $P=0.04)$, and all stroke $(23.6 \%, P=0.056)$ but no differences in myocardial infarction and cardiovascular mortality in the candesartan-treated cohort. The proportions of patients who had a significant cognitive decline or developed dementia were similar in the two treatment groups. ${ }^{50}$ In a predefined subgroup analysis of patients with isolated systolic hypertension, candesartan-based therapy was associated with a $42 \%$ risk reduction ( $P=0.049$ adjusted for baseline risk) despite similar BP control (difference between treatments $2 / 1 \mathrm{mmHg}$; $P=0.101$ and 0.064). ${ }^{51}$

The Acute Candesartan Cilexetil Therapy in Stroke Survivors (ACCESS) study was a Phase II multicenter doubleblind placebo controlled trial designed to assess the safety of modest BP reduction by candesartan cilexetil in the early treatment of stroke. ${ }^{52}$ Five hundred patients were enrolled. The trial was stopped prematurely when 342 patients (339 valid) had been randomized because of an imbalance in endpoints. However, the trial reported that, in the absence of blood pressure lowering, candesartan treatment for 7 days, started within 24 hours of motor deficit associated with stoke, reduced the cumulative 12-month mortality rate (7.2 and $2.9 \%$ for placebo and candesartan, respectively) and vascular events (18.7 and 9.8\% for placebo and candesartan, respectively). Demographic data, cardiovascular risk factors, and BP on admission, on study onset, and within the whole study period were not significantly different between the two groups, nor were there significant differences in concomitant medication and in number or type of side effects. The authors concluded that early initiation of low-dose candesartan was safe in acute stroke, and may provide therapeutic benefits. BP reduction is clearly important in secondary prevention and candesartan is a safe and effective therapeutic option.

These results have not been confirmed in the recently published and much larger PRoFESS trial of another ARB, telmisartan, in the management of acute stroke..$^{53}$

The evidence of added benefit from the use of ARB therapy in patients with recent stroke disease is therefore not compelling at present but further, larger scale, studies on the initiation of ARB therapy within 24 hours of the onset of motor deficit are needed.

\section{Prehypertension}

Prehypertension is very prevalent, affecting over $30 \%$ of the adult population. The mechanism of elevated risk for cardiovascular events associated with prehyperten- 
sion is presumed to be the same as that of hypertension. The Seventh Report of the Joint National Committee on Prevention, Detection, Evaluation, and Treatment of High Blood Pressure ${ }^{54}$ emphasizes the importance of lifestyle measures, with weight control and exercise as the mainstay of therapy, except for higher risk people such as those with diabetes, chronic kidney disease, and known coronary artery disease.

The Trial of Preventing Hypertension (TROPHY) study recruited people with 'high normal blood pressure' who were randomized to 4 years of placebo $(n=381)$ or 2 years of $16 \mathrm{mg} /$ day of candesartan $(\mathrm{n}=391)$ followed by 2 years of placebo. At 2 years, there was a $26.8 \%$ absolute and a $66.3 \%$ relative risk reduction $(P<0.0001)$ of hypertension in the candesartan-treated group. At study end, the former candesartan group had a $9.8 \%$ absolute and a $15.6 \%$ relative risk reduction $(P<0.007)$ of hypertension. The treatment was well tolerated. The TROPHY trial is the first trial of pharmacological intervention in people with prehypertension. As such it has stimulated debate about this approach, ${ }^{55,56}$ but, since the clinical and financial implications of treating over one third of the adult population are substantial, larger scale clinical outcome trials are needed before this can be widely advocated.

\section{Chronic heart failure}

The central role of RAAS system blockade in the treatment of chronic congestive heart failure is well established. There is a large body of endpoint clinical trial data supporting the benefits of ACE inhibitors in heart failure management, with reported reductions of $23 \%$ in total mortality, of $35 \%$ in a combined endpoint of mortality or hospitalization for heart failure.$^{57}$ A recently published meta-analysis of 18,160 patients enrolled in nine trials which met the inclusion criteria reported a $2.3 \%$ increased risk of developing any adverse effect $(P<0.00001)$. Risks predictably included hypotension, worsening renal function and hyperkalemia. The authors concluded that ARBs should not routinely be added to ACE inhibitor therapy for left ventricular dysfunction. If chosen in higher risk patients, for example those with ejection fractions below $40 \%$ and continued symptoms despite ACE inhibitor and $\beta$-blocker therapy, ${ }^{58}$ the combination strategy warrants closer patient monitoring to detect adverse effects.

\section{Atrial fibrillation}

Further analysis of CHARM results also shows a reduced incidence of atrial fibrillation in patients on candesartan. Of the 7601 patients in the overall CHARM population, 6379 did not have atrial fibrillation at baseline and these patients were included in the new secondary analysis. This showed at a median follow-up of 37.7 months that $5.55 \%$ of patients in the candesartan group were reported to have experienced one or more episodes of atrial fibrillation compared with $6.74 \%$ in the placebo group $(P=0.048)$. The relative risk reduction for the incidence of atrial fibrillation was $17.7 \%$ for candesartan treatment compared with placebo. This reduction was observed across all groups of heart failure. ${ }^{59}$ These results are consistent with those from previous trials, which have indicated that ARBs may reduce atrial fibrillation. ${ }^{60,61}$

According to Roland E Schmieder et al RAS inhibition is an emerging treatment for the primary and secondary prevention of AF but acknowledges the fact that some of the primary prevention trials were post-hoc analyses. Further areas of uncertainty include potential differences among specific RAS inhibitors and possible interactions or synergistic effects with antiarrhythmic drugs. In fact the authors reviewed published clinical trial data on the effects of renin-angiotensin system (RAS) inhibition for the prevention of atrial fibrillation (AF), aiming to define when RAS inhibition is most effective; but individual studies examining the effects of RAS inhibition on AF prevention have reported controversial results. Overall, RAS inhibition reduced the odds ratio for AF by 33\% $(P<0.00001)$, but there was substantial heterogeneity among trials. In primary prevention, RAS inhibition was effective in patients with heart failure and those with hypertension and left ventricular hypertrophy but not in post-myocardial infarction patients overall. In secondary prevention, RAS inhibition was often administered in addition to antiarrhythmic drugs, including amiodarone, further reducing the odds for AF recurrence after cardioversion by $45 \%(P=0.01)$ and in patients on medical therapy by $63 \%(P<0.00001){ }^{62}$

\section{Diabetes prevention}

It has been suggested that RAAS blockade may reduce the development of type 2 diabetes by hemodynamic effects, such as improved delivery of insulin and glucose to peripheral skeletal muscle, and nonhemodynamic effects, including direct effects on glucose transport and insulin signaling pathways, all of which decrease insulin resistance. ${ }^{63}$ Experimental data using mouse models showed that candesartan prevented deterioration of glucose tolerance by providing protection against progressive $\beta$-cell damage in diabetes. ${ }^{64}$ One systematic literature search identified 11 trials which enrolled 66,608 patients. ACE inhibitor or ARB therapy was associated with a $22 \%$ reduction in new-onset type 2 diabetes. ${ }^{65} \mathrm{~A}$ number 
of large clinical trials of RAAS blockade have also reported reductions in new-onset diabetes of between 14 and $34 \%$. ${ }^{66}$ A recent meta-analysis was undertaken to assess the effects of antihypertensive agents on incident diabetes. A systematic review identified 48 randomized groups of 22 clinical trials with 143,153 participants who did not have diabetes at randomization and so were eligible for inclusion. The association of antihypertensive drugs with incident diabetes is therefore lowest for ARB and ACE inhibitors, followed by $\mathrm{CCB}$ and placebo, $\beta$-blockers and diuretics in rank order. ${ }^{67}$ The CASE $\mathrm{J}$ trial, a large-scale outcome study in Japan comparing the ARB candesartan cilexetil and the CCB amlodipine showed a reduction in new diabetes as a secondary outcome. Prespecified analysis of new-onset diabetes showed a significant reduction of $36 \%$ with candesartan compared with amlodipine (HR, 0.64; 95\% CI: 0.43-0.97; $P=0.030$ ). Stratified analysis revealed that this effect was greatest in the obese patients (62\% risk reduction).$^{68} \mathrm{~A}$ similar effect was noted as a secondary outcome in HIJ-Create, which showed new onset rates of diabetes with candesartan and non-ARB standard therapy as $1.1 \%$ and $2.9 \%$, respectively $(P=0.027) .{ }^{69}$

With respect to candesartan, CHARM included the development of type 2 diabetes as a secondary outcome in those patients who did not have a diagnosis of diabetes at entry. ${ }^{53}$ Patients received candesartan (target of $32 \mathrm{mg}$ once daily) or matching placebo for 2-4 years. One hundred and sixty-three $(6.0 \%)$ patients in the candesartan group developed diabetes, compared with $202(7.4 \%)$ in the placebo group, a $28 \%$ relative risk reduction $(P=0.020)$. The composite endpoint of death or diabetes occurred in $692(25.2 \%)$ and $779(28.6 \%)$ in the candesartan and placebo groups, respectively (HR, 0.86; 95\% CI: 0.78-0.95; $P=0.004)$.

A further small study ${ }^{70}$ suggests an improved earlyphase insulin response in patients with hypertension with impaired glucose tolerance in association with candesartan treatment, which may delay or prevent the development of insulin resistance and diabetes. Patients with hypertension and impaired glucose tolerance were randomly divided into two groups: group A $(n=6)$, who received $8 \mathrm{mg} /$ day of oral candesartan for 3 months, and controls $(n=6)$. Before and after administration, a $75 \mathrm{~g}$ oral glucose tolerance test was conducted to compare various parameters. No significant differences in age, body mass index (BMI), SBP, DBP, fasting glucose, or fasting immunoreactive insulin were identified between the groups before administration. After 3 months, there were no significant changes in BMI, SBP and DBP for the controls and in BMI and DBP for group A. However, $\mathrm{SBP}$ was significantly decreased from $144 \pm 2.6 \mathrm{mmHg}$ to
$125 \pm 4.6 \mathrm{mmHg}$ in group A. Insulinogenic index tended to be slightly decreased for controls, but was significantly increased from $0.32 \pm 0.0$ to $0.47 \pm 0.1$ for group A.

While these studies provide support for the hypothesis that RAAS blockade may reduce the development of newonset diabetes, recent large-scale trials have failed to confirm this. Neither the Diabetes Reduction Approaches with Ramipril and Rosiglitazone Medications (DREAM) trial with the ACE inhibitor ramipril, in which new-onset diabetes was a primary endpoint, nor the very large ONTARGET found any benefit of ACE inhibitor or ARB therapy in the development of diabetes. The Nateglinide and Valsartan in Impaired Glucose Tolerance Outcomes Research (NAVIGATOR) trial with valsartan is currently ongoing. . $^{71,72}$

There is currently insufficient evidence to support the hypothesis that RAAS blockade with candesartan or other ARBs or ACE inhibitors has a significant effect on the development of diabetes.

\section{Urinary albumin excretion}

RAAS system blockade is accepted as a central management strategy in the treatment of proteinuric renal disease. RAAS is believed to have a major influence on intraglomerular filtration pressure by preferentially regulating post-glomerular efferent arteriolar resistance leading to intra-glomerular hypertension and the potentiation of proteinuria. ${ }^{73}$ Early clinical trials in patients with type 1 diabetes and established renal disease confirmed that an ACE inhibitor based treatment strategy halved the rate of renal deterioration, the need for dialysis and death. ${ }^{74}$ Studies have also confirmed the benefits of ACE inhibition at the earlier microalbuminuric stage of diabetic nephropathy ${ }^{75}$ and also in the progression of normo- to microalbuminuria. ${ }^{76}$ In type 2 diabetes the IDNT $^{77}$ and RENAAL $^{78}$ trials confirm the renal benefits of irbesartan- and losartan-based therapies in patients with established renal disease, and IRMA-II data ${ }^{79}$ confirmed benefit in patients with type 2 diabetes and microalbuminuria. Whether ACE inhibitors or ARBs are superior is a matter of controversy. A Cochrane review in 2004 concluded that the renal benefits of these agents were similar but there were insufficient data to determine whether the ARBs had similar survival benefits to ACE inhibitor therapy. ${ }^{80}$ No cardiovascular outcome benefits were seen in the IDNT, IRMA2 and RENAAL trials.

As a potent long-acting ARB, candesartan would be expected to reduce urine protein excretion in a variety of renal diseases. Early studies in rats suggested beneficial renoprotective effects of candesartan ${ }^{81}$ and an early comparative trial between candesartan and ACE inhibition confirmed 
improvements in proteinuria, with a greater effect seen in the candesartan group. ${ }^{82}$

Murayama and colleagues ${ }^{83}$ reported the benefits of candesartan in patients with early kidney disease independent of its antihypertensive effect. Fifty-two patients with type 2 diabetes with normo- or microalbuminuria participated. Nineteen patients with high normal and mild hypertension received low-dose candesartan (4 mg once daily; candesartan group), and 33 patients did not receive candesartan (control group). Blood pressure, urinary albumin excretion, transferrin, and type IV collagen (expressed as urinary creatinine index) and plasma parameters were determined at baseline and at 2, 6, 12 and 18 months after the start of candesartan therapy. Baseline parameters were similar in both groups. Candesartan treatment decreased the higher baseline SBP to the level of the control group. In the control group, urinary albumin excretion increased significantly at 18 months compared with baseline, while no changes in urinary albumin excretion were reported in the candesartan group.

The antiproteinuric effects of candesartan are dose dependent. In a short-term study of 23 patients with hypertension, type 2 diabetes and nephropathy the effect of four treatment doses of 8,16 or $32 \mathrm{mg}$ candesartan compared with placebo were compared during four treatment periods each lasting 2 months. The trial was double blind and patients received treatment doses in random order. All three candesartan doses significantly reduced albuminuria and 24-hour BP compared with placebo. Mean $(95 \% \mathrm{CI})$ reductions in albuminuria were $33 \%(21-43), 59 \%$ (52-65), and $52 \%$ (44-59) for the 8, 16 and $32 \mathrm{mg}$ dosing schedules, respectively. Higher doses (16 and $32 \mathrm{mg}$ ) were associated with a significantly greater antiproteinuric effect, but there were no differences in reduction of BP between the three doses. $^{84}$

Several studies have investigated whether supra-maximal doses of candesartan may have additional effects to reduce proteinuria. In a pilot study in 2004, Weinberg and colleagues $^{85}$ reported benefits from doses up to $160 \mathrm{mg}$ daily, which is five times higher than the maximal recommended dose. No safety or tolerability issues were reported. A significant relative reduction of $30 \%$ was reported using a $64 \mathrm{mg}$ daily dose of candesartan in 32 patients with diabetic or nondiabetic renal disease when compared with $16 \mathrm{mg}$ daily dosing. ${ }^{86}$ Finally, a recent report suggests there are benefits of using supramaximal doses of candesartan in reducing proteinuria. ${ }^{87}$ Reductions of $33 \%$ were seen using doses of 64 and $128 \mathrm{mg}$ daily compared with $16 \mathrm{mg}$ daily in a trial of 269 patients, mostly with diabetic nephropathy. Whether these reductions are associated with improved long-term renal protection is unknown.

Although much interest has focused on the prevention and treatment of diabetic renal disease, the antiproteinuric effects of candesartan have also been reported in patients with nondiabetic renal diseases, including chronic glomerulonephritis, ${ }^{88}$ renal transplant recipients ${ }^{89}$ and patients with adult polycystic kidney disease. ${ }^{90}$

Dual blockade using ACE inhibitors and ARBs in combination has received considerable interest over the last 10 years. The Candesartan and Lisinopril Microalbuminuria (CALM) trial first reported improved control of blood pressure and reduced proteinuria using this combination. ${ }^{91}$ CALM was a randomized double-blind trial in 199 patients aged 30-75 years with type 2 diabetes, microalbuminuria (urinary albumin: creatinine ratio $2.5-25 \mathrm{mg} / \mathrm{mmol}$ ), and DBP between 90 and $110 \mathrm{mmHg}$. Patients were allocated to one of four groups: candesartan for 24 weeks $(n=66)$, lisinopril for 24 weeks $(n=64)$, candesartan for 12 weeks with the addition of lisinopril for a subsequent 12 weeks ( $n=34$ ), or lisinopril for 12 weeks with the addition of candesartan for a subsequent 12 weeks $(n=35)$. At 24 weeks, mean DBP was lower with combination treatment (16.3 $\mathrm{mmHg})$ than with candesartan $(10.4 \mathrm{mmHg} ; P=0.003)$ or lisinopril monotherapy $(10.7 \mathrm{mmHg} ; P=0.005)$. Similar benefits were seen in SBP with combination treatment. Combination treatment was associated with a greater mean reduction from baseline in urinary albumin to creatinine ratio than candesartan alone $(50 \%$ versus $24 \% ; P=0.04)$ but not lisinopril alone $(50 \%$ versus $39 \% ; P>0.20)$. Since this early report several small, short-term studies have reported similar benefits. ${ }^{92-94}$ More recently the CALM-2 trial ${ }^{95}$ did not find any difference between lisinopril $40 \mathrm{mg}$ daily compared with lisinopril $16 \mathrm{mg}$ daily plus the addition of candesartan $16 \mathrm{mg}$ daily during a 12-month follow-up period. Urinary albumin excretion remained stable through the follow-up period in both groups, with no significant differences between the two regimens.

The problem with these studies is their short follow-up, small numbers of study participants and the use of surrogate markers (BP and urine albumin secretion) rather than clinically relevant hard endpoints.

Taken together these data cast significant doubt on the utility of dual RAAS blockade using ACE inhibitors and ARBs, particularly in patients with low-level $(<1 \mathrm{G}$ per day) proteinuria. In patients with high-range proteinuria, the addition of candesartan to ongoing ACE inhibitor treatment may be considered, but patients on this combination would require careful 
monitoring of BP, serum potassium, proteinuria and renal function to ensure safety.

\section{Retinopathy}

The growing evidence of local RAAS within the eye which is activated in diabetes, combined with the reported benefits of the ACE inhibitor lisinopril in retinopathy in the EUCLID trial, formed the rationale for the Diabetic Retinopathy Candesartan Trials (DIRECT) clinical trial programme. Local RAS is believed to be responsible, either directly or via other mediators, for increased concentrations of vascular endothelial growth factor, a selective angiogenic and vasopermeability factor implicated in the pathogenesis of diabetic retinopathy.

It has been suggested that inhibition of ACE or blockade of angiotensin II could reduce vascular endothelial growth factor concentrations and favourably influence the development or progression of retinopathy.

The DIRECT programme was designed to assess whether candesartan could reduce the incidence and progression of retinopathy in type 1 diabetes and the progression of retinopathy in type 2 diabetes. The programme consisted of three randomized, double-blind, parallel-design, placebo-controlled trials; two in patients with type 1 diabetes and a third in patients with type 2 diabetes. The DIRECT-Prevent 1 trial recruited participants with normotensive, normoalbuminuric type 1 diabetes without retinopathy. Participants with type 1 diabetes and existing mild-moderate retinopathy were recruited to DIRECT-Protect 1. Participants were assigned to candesartan $16 \mathrm{mg}$ once a day or matching placebo. After 1 month the dose was doubled to $32 \mathrm{mg}$. The primary endpoints were incidence and progression of retinopathy and were defined as at least a two-step and at least a three-step increase on the Early Treatment Diabetic Retinopathy Study (ETDRS) scale, respectively. New retinopathy developed in 178 (25\%) participants in the candesartan group versus 217 (31\%) in the placebo group. Progression of retinopathy occurred in 127 (13\%) participants in the candesartan group versus $124(13 \%)$ in the placebo group. Hazard ratio (HR for candesartan vs placebo) was 0.82 (95\% CI: $0.67-1.00 ; P=0.0508$ ) for incidence of retinopathy and 1.02 (95\% CI: $0.80-1.31 ; P=0.85)$ for progression of retinopathy.

Final ETDRS level was more likely to have improved with candesartan treatment in both DIRECT-Prevent 1 (OR, 1.16; 95\% CI: $1.05-1.30 ; P=0.0048)$ and DIRECT-Protect 1 (OR, 1.12; 95\% CI:1.01-1.25; $P=0.0264)$. The investigators hypothesized that candesartan reduces the incidence of retinopathy, although they did not see a beneficial effect on retinopathy progression in type 1 diabetes. ${ }^{96}$

The DIRECT-Protect 2 programme studied people with type 2 diabetes and retinopathy at enrolment. The study examined whether candesartan treatment could slow the progression and, secondly, induce regression of retinopathy.

Patients with type 2 diabetes who were normoalbuminuric, normotensive or treated hypertensive with mild to moderately severe retinopathy were recruited and assigned to candesartan $16 \mathrm{mg}$ once a day or placebo which was subsequently increased to $32 \mathrm{mg}$.

A total of $161(17 \%)$ patients in the candesartan group and $182(19 \%)$ in the placebo group had progression of retinopathy by three steps or more on the ETDRS scale. The risk of progression of retinopathy was nonsignificantly reduced by $13 \%$ in patients on candesartan compared with those on placebo (HR, 0.87; 95\% CI: $0.70-1.08 ; P=0.20$ ). Regression on active treatment was increased by $34 \%$ (HR, 1.34; 95\% CI: $1.08-1.68 ; P=0.009)$. An overall change towards less severe retinopathy by the end of the trial was observed in the candesartan group (OR, 1.17; 95\% CI: 1.05-1.30; $P=0.003)$.

Hence the investigators suggested that treatment with candesartan in patients with type 2 diabetes and mild to moderate retinopathy might induce improvement of retinopathy. ${ }^{97}$

The DIRECT trial programme provides reassurance on the long-term safety of candesartan in a large patient population, with no reported differences between treatment groups.

\section{My evidence}

In a recent my paper a population of 154 patients aged 40 to 66 years, was studied, with WHO I-II stage essential hypertension, and electrocardiographic left ventricular

Table 3 Functional capacity at the various treatment steps (mean \pm SD)

\begin{tabular}{|c|c|c|c|c|}
\hline & $\mathbf{P I}$ & $\mathbf{P I}+\mathbf{A s p}$ & Can & Can + Asp \\
\hline Oxygen consumption at peak exercise $(\mathrm{ml} / \mathrm{min} / \mathrm{kg})$ & $15 \pm 3.5$ & $14 \pm 5.6$ & $17 \pm 3.2^{*}$ & $17.1 \pm 3.1^{*}$ \\
\hline Dead space/Tidal volume ratio & $0.21 \pm 0.03$ & $0.22 \pm 0.06$ & $0.18 \pm 0.04 *$ & $0.18 \pm 0.04^{*}$ \\
\hline Exercise tolerance time(s) & $514 \pm 186$ & $515 \pm 132$ & $580 \pm 169 *$ & $602 \pm 26^{*}$ \\
\hline
\end{tabular}

Notes: *Difference from Pl and from PI+Asp is significant at $P<0.01$. Copyright $@ 2009$, John Wiley and Sons. Reproduced with permission from De Rosa ML, Chiariello M. Candesartan improves maximal exercise capacity in hypertensives: results of a randomized placebo-controlled crossover trial. J Clin Hypertens. 2009 ; I I (4): I92-200.

Abbreviations: PI, placebo; Asp, aspirin; Can, candesartan. 
Table 4 Maximal exercise blood pressure and heart rate and oxygen reserve and LVM at the various treatment

\begin{tabular}{lllll}
\hline Steps (mean \pm SD) & PI & PI + Asp & Can & Can + Asp \\
\hline Maximal systolic BP $(\mathrm{mmHg})$ & $202 \pm 4$ & $203 \pm 4$ & $192 \pm 5^{*}$ & $190 \pm 4^{*}$ \\
$\Delta$ systolic BP & $55 \pm 4$ & $56 \pm 3$ & $58 \pm 5$ & $58 \pm 4$ \\
Maximal diastolic BP (mmHg) & $99 \pm 5$ & $92 \pm 2$ & $85 \pm 3^{*}$ & $78 \pm 2^{*}$ \\
$\Delta$ diastolic BP & $5 \pm 5$ & $5 \pm 4$ & $6 \pm 3$ & $6 \pm 4$ \\
Maximal Heart Rate (b/min) & $161 \pm 4$ & $166 \pm 2$ & $170 \pm 5^{*}$ & $176 \pm 3^{*}$ \\
$\Delta$ Heart Rate & $84 \pm 4$ & $84 \pm 3$ & $96 \pm 4^{*}$ & $98 \pm 4^{*}$ \\
VO2 rest/mass (ml/kg/min) & $4 \pm 3$ & $4 \pm 2$ & $4 \pm 4$ & $4 \pm I$ \\
LV mass (g) & $170 \pm 4$ & $170 \pm 8$ & $169 \pm 2^{*}$ & $3 \pm 0.4^{*}$ \\
Oxygen reserve (ratio) & $3.8 \pm 0.3$ & $3.5 \pm 0.24$ & $19 \pm 0.4$ & $4.3 \pm 0.3^{*}$ \\
$\Delta$ effort (Borg scale) & $19 \pm 0.3$ & $19 \pm 0.2$ & $19 \pm 0.2$ \\
\hline
\end{tabular}

Notes: $\Delta=$ change with exercise *Difference from PI and from PI + Asp is significant at $P<0.01$. Copyright $@ 2009$, John Wiley and Sons. Reproduced with permission from De Rosa ML, Chiariello M. Candesartan improves maximal exercise capacity in hypertensives: results of a randomized placebo-controlled crossover trial. J Clin Hypertens. 2009; I I (4): 192-200.98

hypertrophy. They were randomized to receive placebo, candesartan (32 mg), each of these plus aspirin (300 mg/day), or the same preparations in a reverse order, each for 3 weeks, with a 3-week wash out period between treatments. Maximal workload and oxygen reserve were measured cardiopulmonary exercise test, 24-hour ambulatory BP, LV mass index by echocardiography according to American Heart Association recommendations, at the end of each treatment.

The patients did not achieve the maximal workload as predicted by age, gender and weight and height [116 (99-133) vs 132 (116-149) Watts, $P=0.01]$. This impaired exercise capacity, calculated as the ratio between achieved and predicted maximal workload was in multiple regression analysis related to lower oxygen reserve $(\mathrm{r}=0.49, P<0.001)$, and the lower oxygen reserve to higher echo LVH $(\beta=-0.34)$, respectively.

Candesartan alone or with aspirin caused an improvement of VO2 and exercise tolerance, which was absent in controls (Tables 3-4).

Considering that hypertrophy and remodeling in patients with untreated hypertension have been associated with impaired exercise capacity, candesartan was tested to see whether it improved exercise peak oxygen volume (VO2) in this population.

Thus, hypertensives cannot achieve the predicted maximal workload. This impaired exercise capacity was related to lower oxygen reserve while peak VO2 may be (NYHA class) the strongest prognostic factor in this population.

Furthermore, candesartan may represent an alternative or even an advancement in hypertensives for its efficacy on exercise $\mathrm{VO} 2$ and exercise tolerance, without antagonism by aspirin..$^{98}$

\section{Conclusions}

Candesartan has shown benefit in the treatment of hypertension. It has been shown to be more effective than losar$\tan ^{43}$ in a number of studies. Candesartan has also shown effectiveness when combined with hydrochlorothiazide and good tolerability in this setting. ${ }^{45}$ This combination has been shown to be both safe and effective in the treatment of severe hypertension. ${ }^{46,47}$

As well as showing reduction in blood pressure, candesartan has also shown benefits in terms of hypertension endpoint studies. SCOPE showed significant reductions in nonfatal stroke $(27.8 \% ; P=0.04)$ and all stroke $(23.6 \% ; P=0.049) .{ }^{51}$ ACCESS looked at the early initiation of candesartan following stroke. This trial reported that, despite the absence of BP lowering, candesartan treatment for 7 days, started within 24 hours of motor deficit associated with stoke, reduced the cumulative 12 -month mortality rate (7.2 and $2.9 \%$ for placebo and candesartan, respectively) and vascular events (18.7 and $9.8 \%$ for placebo and candesartan, respectively). ${ }^{52}$

Candesartan has also been studied in the prevention of hypertension in the setting of prehypertension. TROPHY is the first such trial in this group of patients. It showed a $9.8 \%$ absolute and a $15.6 \%$ relative risk reduction $(P<0.007)$ of hypertension. As this is the first such trial, others will be required to further validate this approach but the implications are far reaching. ${ }^{55,56}$

One of the major areas of importance for candesartan is in the treatment of heart failure, with a reduced ejection fraction below $40 \%$. CHARM showed reduction in cardiovascular death and congestive heart failure hospitalization versus placebo when both used as an alternative to ACE inhibitor therapy ( $\mathrm{HR}=0.7 ; P<0001)$ or when added to ACE inhibitor therapy $(\mathrm{HR}=0.85 ; P<0.01) .{ }^{58}$ Interestingly, CHARM also 
showed that candesartan reduced the incidence of new atrial fibrillation. ${ }^{59}$

Candesartan has shown a benefit in diabetes prevention. Both the CASE trial and HIJ-Create have shown a reduction in new incidence of diabetes in patients using candesartan. CASE-J showed a significant effect when compared with amlodipine (HR, 0.64; 95\% CI: $0.43-0.97 ; P=0.030$ ) and HIJ-Create showed reduced incidence compared with nonARB treatment $(P=0.027) \cdot{ }^{67,68}$

Data also support its use in patients with proteinuric renal disease as an alternative should an ACE inhibitor not be tolerated, although it should be remembered that it does not have a specific licence for this indication. ARBs have been shown to be beneficial in patients with established renal disease (RENALL, IDNT) and have shown similar benefits to ACE inhibitor therapy. ${ }^{77,78}$ Dual blockade using both ACE inhibitors and ARBs has been tried. CALM showed a larger reduction in $\mathrm{BP}$ with the combination of candesartan and lisinopril than with monotherapy $(13.3 \mathrm{mmHg}$ combination; $10.4 \mathrm{mmHg}, P=0.003$ candesartan; $10.7 \mathrm{mmHg}, P=0.005$ lisinopril). There was a reduction from baseline in urinary albumin to creatinine ratio when candesartan was used in combination versus alone $(50 \%$ versus $24 \% ; P=0.04) .{ }^{91}$

The recent DIRECT study supports the use of candesartan in patients with early stage retinopathy. Candesartan reduced the incidence of retinopathy in DIRECT-Prevent 1. DIRECT Protect 2 showed a change towards less severe retinopathy in the candesartan group versus the placebo group (OR, 1.17; 95\% CI: $1.05-1.30 ; P=0.003) .{ }^{96,97}$

Overall candesartan is a very safe, well tolerated drug from the group of ARBs. Its pleiotropic effects ensure that it has wide-ranging implications for clinical use with an ever expanding wealth of evidence to support its ongoing and widening usage.

Hypertensives had lower measures of peakVO2, oxygen reserve and heart rate at maximal exercise than predicted by age, gender, weight and height.

In my crossover and placebo-controlled study in patients with mild to moderate hypertension, candesartan mono therapy produces a significantly lower arterial BP than placebo or placebo plus aspirin at week 3 of treatment while a combination of candesartan and aspirin yielded a better physical performance and exercise oxygen uptake compared with either drug alone. Furthermore, candesartan may represent an alternative in hypertensive patients for its efficacy on exercise peak VO2 and exercise tolerance, because of similar efficacy of ACE inhibitor for exercise performance and less exposure to the counteracting activity of aspirin. ${ }^{98}$
ARBs have established themselves as versatile agents for the treatment of a variety of conditions throughout the $\mathrm{CV}$ continuum. While the accumulation of evidence with ARBs has involved clinical trials with a number of different individual agents, in addition to candesartan, other ARBs such as valsartan, telmisartan, and losartan have demonstrated benefits on major CV endpoints. Pharmacological studies have highlighted the differences among AT1-receptor blockers, and confirmed the tight receptor binding and long-acting properties of candesartan.

\section{Disclosure}

The author declares no conflicts of interest.

\section{References}

1. Dahlöf B, Devereux RB, Kjeldsen SE, et al. Cardiovascular morbidity and mortality in the Losartan Intervention For Endpoint reduction in hypertension study (LIFE): a randomised trial against atenolol. Lancet. 2002;359(9311):995-1003.

2. Lithell H, Hansson L, Skoog I, et al. The Study on Cognition and Prognosis in the Elderly (SCOPE): principal results of a randomized double-blind intervention trial. J Hypertens. 2003;21(5):875-886.

3. Julius S, Kjeldsen SE, Weber M, et al; VALUE trial group. Outcomes in hypertensive patients at high cardiovascular risk treated with regimens based on valsartan or amlodipine: the VALUE randomised trial. Lancet. 2004;363(9426):2022-2031.

4. World Health Organization: Cardiovascular disease: prevention and control. Accessed on-line at www.who.int, 2009 Apr.

5. Public Health Agency of Canada: Leading Causes of Death and Hospitalization in Canada. Accessed on-line at http://www.phac-aspc.gc.ca, 2009 Apr.

6. Dzau VJ, Antman EM, Black HR, et al. The cardiovascular disease continuum validated: clinical evidence of improved patient outcomes: part I: Pathophysiology and clinical trial evidence (risk factors through stable coronary artery disease). Circulation. 2006;114(25):2850-2870.

7. Mochizuki S, Dahlöf B, Shimizu M, et al. Valsartan in a Japanese population with hypertension and other cardiovascular disease (Jikei Heart Study): a randomised, open-label, blinded endpoint morbidity-mortality study. Lancet. 2007;369(9571): 1431-1439.

8. ONTARGET Investigators, Yusuf S, Teo KK, et al. Telmisartan, ramipril, or both in patients at high risk for vascular events. $N$ Engl J Med. 2008;358(15):1547-1559.

9. TRANSCEND Investigators. Effects of the angiotensin-receptor blocker telmisartan on cardiovascular events in high-risk patients intolerant to angiotensin-converting enzyme inhibitors: a randomised controlled trial. Lancet. 2008;372:1174-1183.

10. Schrader J, Lüders S, Kulschewski A, et al. Morbidity and Mortality After Stroke, Eprosartan Compared with Nitrendipine for Secondary Prevention: principal results of a prospective randomized controlled study (MOSES). Stroke. 2005;36(6):1218-1226.

11. Yusuf S, Diener HC, Sacco RL, et al. Telmisartan to prevent recurrent stroke and cardiovascular events. N Engl J Med. 2008;359(12): 1225-1237.

12. Dickstein K, Kjekshus J; OPTIMAAL Steering Committee of the OPTIMAAL Study Group. Effects of losartan and captopril on mortality and morbidity in high-risk patients after acute myocardial infarction: the OPTIMAAL randomised trial. Optimal Trial in Myocardial Infarction with Angiotensin II Antagonist Losartan. Lancet. 2002; 360(9335):752-760. 
13. Pfeffer MA, McMurray JJ, Velazquez EJ, et al. Valsartan, captopril, or both in myocardial infarction complicated by heart failure, left ventricular dysfunction, or both. N Engl J Med. 2003;349(20): 1893-1906.

14. Pfeffer MA, Braunwald E, Moyé LA, et al. Effect of captopril on mortality and morbidity in patients with left ventricular dysfunction after myocardial infarction: results of the Survival and Ventricular Enlargement trial. N Engl J Med. 1992;327:669-677.

15. Effect of ramipril on mortality and morbidity of survivors of acute myocardial infarction with clinical evidence of heart failure. The Acute Infarction Ramipril Efficacy (AIRE) Study Investigators. Lancet. 1993;342(8875):821-828.

16. Køber L, Torp-Pedersen C, Carlsen JE, et al: A clinical trial of the angiotensin-converting-enzyme inhibitor trandolapril in patients with left ventricular dysfunction after myocardial infarction. Trandolapril Cardiac Evaluation (TRACE) Study Group. $N$ Engl J Med. 1995; 333(25):1670-1676.

17. McMurray J, Solomon S, Pieper K, et al. The effect of valsartan, captopril, or both on atherosclerotic events after acute myocardial infarction: an analysis of the Valsartan in Acute Myocardial Infarction Trial (VALIANT). J Am Coll Cardiol. 2006;47(4):726-733.

18. Pitt B, Poole-Wilson PA, Segal R, et al. Effect of losartan compared with captopril on mortality in patients with symptomatic heart failure: randomised trial - the Losartan Heart Failure Survival Study ELITE II. Lancet. 2000;355(9215):1582-1587.

19. Pitt B, Segal R, Martinez FA, et al. Randomised trial of losartan versus captopril in patients over 65 with heart failure. Lancet. 1997;349: $747-752$.

20. Cohn JN, Tognoni G. Valsartan Heart Failure Trial Investigators. A randomized trial of the angiotensin-receptor blocker valsartan in chronic heart failure. $N$ Engl J Med. 2001;345(23):1667-1675.

21. Pfeffer MA, Swedberg K, Granger CB, et al. Effects of candesartan on mortality and morbidity in patients with chronic heart failure: the CHARM-Overall program. Lancet. 2003;362(9386):759-766.

22. McMurray JJ, Ostergren J, Swedberg K, et al. Effects of candesartan in patients with chronic heart failure and reduced left-ventricular systolic function taking angiotensin-converting-enzyme inhibitors: the CHARM-Added trial. Lancet. 2003;362(9386):767-771.

23. Granger CB, McMurray JJ, Yusuf S, et al. Effects of candesartan in patients with chronic heart failure and reduced left-ventricular systolic function intolerant to angiotensin-converting-enzyme inhibitors: the CHARM-Alternative trial. Lancet. 2003;362(9386):772-776.

24. Yusuf S, Pfeffer MA, Swedberg K, et al. Effects of candesartan in patients with chronic heart failure and preserved left-ventricular ejection fraction: the CHARM-Preserved Trial. Lancet. 2003;362(9386):777-781.

25. Massie BM, Carson PE, McMurray JJ, et al. Irbesartan in patients with heart failure and preserved ejection fraction. $N$ Engl J Med. 2008; 359(23):2456-2467.

26. Fitchett D. Results of the ONTARGET and TRANSCEND studies: an update and discussion. Vasc Health Risk Manag. 2009;5(1):21-29.

27. The ACTIVE Steering Committee; ACTIVE Investigators, Connolly S, et al. Rationale and design of ACTIVE: the atrial fibrillation clopidogrel trial with irbesartan for prevention of vascular events. Am Heart J. 2006 151(6):1187-1193.

28. Cooper CJ, Murphy TP, Matsumoto A, et al. Stent revascularization for the prevention of cardiovascular and renal events among patients with renal artery stenosis and systolic hypertension: rationale and design of the CORAL trial. Am Heart J. 2006;152(1):59-66.

29. Sawada T, Takahashi T, Yamada H, et al. Rationale and design of the KYOTO HEART study: effects of valsartan on morbidity and mortality in uncontrolled hypertensive patients with high risk of cardiovascular events. J Hum Hypertens. 2009;23(3):188-195.

30. Comparison of Valsartan With Amlodipine in Hypertensive Patients With Glucose Intolerance. www.clinicaltrials.gov. Accessed April 2009.

31. The NAVIGATOR Trial Steering Committee. Nateglinide and valsartan in impaired glucose tolerance outcomes research: rationale and design of the NAVIGATOR trial (Abstract). Diabetes. 2002;51:A116.
32. Haller H, Viberti GC, Mimran A, et al. Preventing microalbuminuria in patients with diabetes: rationale and design of the Randomised Olmesartan and Diabetes Microalbuminuria Prevention (ROADMAP) study. J Hypertens. 2006;24(2):403-408.

33. The Internet Stroke Center. Stroke Trials Registry, www.strokecenter. org. Accessed April 2009.

34. Ogihara T, Saruta T, Matsuoka H, et al. Valsartan in elderly isolated systolic hypertension (VALISH) study: rationale and design. Hypertens Res. 2004;27(9):657-661.

35. Nakayama K, Kuwabara Y, Daimon M, et al. Valsartan Amlodipine Randomized Trial (VART): design, methods, and preliminary results. Hypertens Res. 2008;31(1):21-28.

36. Sever PS, Gradman AH, Azizi M. Managing cardiovascular and renal risk: the potential of direct renin inhibition. J Renin Angiotensin Aldosterone Syst. 2009;10(2):65-76.

37. Vanderheyden PML, Fierens FLP, Vauquelin G. Angiotensin II type 1receptor antagonists. Why do some of them produce insurmountable inhibition? Biochem Pharmacol. 2000;60:1557.

38. Vauquelin G, Fierens FLP, Vanderheyden PML. Distinction between surmountable and insurmountable angiotensin II AT1 receptor antagonists. In: Epstein M, Brunner HR, (Editors). Angiotensin II receptor antagonists. Philadelphia, PA: Hanley and Belful, 2000:105-18.

39. Vanderheyden PML, Fierens FLP, De Backer JP, et al. Distinction between surmountable and insurmountable selective AT1 receptor antagonists by use of CHO-K1 cells expressing human angiotensin II AT1 receptors. Br J Pharmacol. 1999;126:1057-1065.

40. Severs PS, Holzgreve H. Long-term efficacy and tolerability of candesartan cilexetil in patients with mild to moderate hypertension. J Hum Hypertens. 1997;11(Supp1 2):S69-S73.

41. New Zealand emedicines and medical devices safety authority data sheet. Available from: www.medsafe.govt.nz/profs/datasheet/a/ Atacandtab.htm [Accessed 13 June 2009].

42. Severs P. Candesartan cilexetil: a new, long-acting, effective angiotensin II type 1 receptor blocker. J Hum Hypertens. 1997;11(Suppl 2:)S91-S95.

43. Vit D, White W, Ridley E, et al. A forced titration study of antihypertensive efficacy of candesartan cilexetil in comparison to losartan: CLAIM Study II. J Hum Hypertens. 2001;15:475-480.

44. Macgregor G, Viskopfer J, Antonios T, Feng J. (UK and Israel Candesartan Investigators): Efficacy of candesartan cilexetil alone or in combination with amlodipine and hydrochlorothiazide in moderateto-severe hypertension. Hypertension. 2000;36:454.

45. Fogari R, Mugellini A, Derosa G. CANDIA (Candesartan and diuretic vs amlodipine in hypertensive patients) Study Group: efficacy and tolerability of candesartan cilexetil/hydrochlorothiazide and amlodipine in patients with poorly controlled mild-to-moderate essential hypertension. J Renin Angiotensin Aldosterone Syst. 2007;8(3): 139-144.

46. Oparil S, Levine J, Zushke C, et al. Effects of candesartan cilexetil in patients with severe systemic hypertension. Candesartan Cilexetil Study Investigators. Am J Cardiol. 1999;84(3):289-293.

47. Oparil S. Candesartan cilexetil in combination with low-dose hydrochlorothiazide is effective in severe hypertension. Am J Cardiol. 1999;84(10A):35S-41S.

48. Sever P. Clinical profile of the novel angiotensin II type I blocker candesartan cilexetil. J Hypertens Suppl. 1997;15(6):S9-S12.

49. Taavitsainen P, Kiukaanniemi K, Pelkonen O. In vitro inhibition screening of human hepatic P450 enzymes by five angiotensin-II receptor antagonists. Eur J Clin Pharmacol. 2000;56(2):135-140.

50. Lithell P, Hansson L, Skoog I, et al. SCOPE Study Group. The study on cognition and prognosis in the elderly (SCOPE): principal results of a randomized double-blind intervention trial. J Hypertens. 2003;21(5):875-886.

51. Papademetriou V, Farsang C, Elmfeldt D, et al. Study on cognition and prognosis in the elderly study group. Stroke prevention with the angiotensin II type 1-receptor blocker candesartan in elderly patients with isolated systolic hypertension: the Study on Cognition and Prognosis in the Elderly (SCOPE). J Am Coll Cardiol. 2004;44(6):1175-1180. 
52. Schrader J, Luders S, Kuschewski A, et al. Acute Candesartan Cilexetil Therapy in Stroke Survivors Study Group. The ACCESS study: evaluation of acute candesartan cilexetil therapy in stroke survivors. Stroke. 2003;34(7):1699-1703.

53. Yusuf S, Ostergreb J, Gerstein H, et al. Candesartan in Heart FailureAssessment of Reduction in Mortality and Morbidity Program Investigators. Effects of candesartan on the development of a new diagnosis of diabetes mellitus in patients with heart failure. Circulation. 2005;112(1):48-53

54. Chobanian Abakris G, Black H, Cushman W, et al. The National High Blood Pressure Education Program Coordinating Committee. Seventh report of the Joint National Committee on Prevention, Detection, Evaluation, and Treatment of High Blood Pressure. Hypertension. 2003;42:1206

55. Papadopolous D, Makris T, Papademtriou V. Is it time to treat prehypertension? Hypertens Res. 2008;31(9):1681-1686.

56. Egan B, Nesbitt S, Julius S. Prehypertension: should we be treating with pharmacologic therapy? Ther Adv Cardiovasc Dis. 2008;2(4): 305-314.

57. Garg R, Yusuf S. Overview of randomized trials of angiotensinconverting enzyme inhibitors on mortality and morbidity in patients with heart failure. Collaborative Group on ACE Inhibitor Trials. JAMA. 1995;273(18):1450-1456.

58. The Task Force for the Diagnosis and Treatment of Acute and Chronic Heart Failure 2008 of the European Society of Cardiology. ESC guidelines. Eur Heart J. 2008;29:22388-22442.

59. Ducharme A, Swedberg K, Pfeffer M, et al. Prevention of atrial fibrillation in patients with symptomatic chronic heart failure by candesartan in the Candesartan in Heart Failure: Assessment of Reduction in Mortality and Morbidity (CHARM) program. Am Heart J. 2006;152(1):86-92.

60. Maggioni A, Latini R, Carson P, et al. Valsartan reduces the incidence of atrial fibrillation in patients with heart failure: results from the Valsartan Heart Failure Trial (Val-HeFT). Am Heart J. 2005;149:548-547.

61. Wachtell K, Lehto M, Gerdts E, et al. Angiotensin II receptor blockade reduces new-onset atrial fibrillation and subsequent stroke compared to atenolol: the Losartan Intervention For End Point Reduction in Hypertension (LIFE) study. $J$ Am Coll Cardiol. 2005;45:712-719.

62. Markus P, Schneider MD*, Tsushung A. Hua, $\mathrm{PhD}^{\dagger}$, Michael Böhm, $\mathrm{MD}^{\ddagger}$, Kristian Wachtell, $\mathrm{MD}, \mathrm{PhD}^{\S}$, Sverre E. Kjeldsen, $\mathrm{MD}, \mathrm{PhD}^{\|}$and Roland E. Schmieder MD, Prevention of Atrial Fibrillation by ReninAngiotensin System Inhibition. A Meta Analysis. $J$ Am Coll Cardiol. 2010;55:2299-2307.

63. Jandeleit-Dahm K, Tikellis C, Reid C, et al. Why blockade of the renin-angiotensin system reduces the incidence of new-onset diabetes. J Hypertens. 2005;23(3):463-473.

64. Jiaqing Shao, Iwashita N, Ikeda F, et al. Beneficial effects of candesartan, an angiotensin II type 1 receptor blocker, on $\beta$-cell function. Biochemical and biophysical research communications and morphology in $\mathrm{db} /$ $\mathrm{db}$ mice. Biochem Biophys Res Commun. 2006;344(4):1224-1233.

65. Gillespie E, White C, Kardas M, et al. The impact of ACE inhibitors or angiotensin II type 1 receptor blockers on the development of new-onset type 2 diabetes. Diabetes Care. 2005;28:2261-2266.

66. Scheen A. Prevention of type 2 diabetes mellitus through inhibition of the Renin-angiotensin system. Drugs. 2004;64(22): $2537-2565$

67. Elliott W, Meyer P. Incident diabetes in clinical trials of antihypertensive drugs: a network meta-analysis. The Lancet. 2007;369(9557): 201-207.

68. Ogihara T, Nakao K, Fukui T, et al. Effects of candesartan compared with amlodipine in hypertensive patients with high cardiovascular risks: candesartan antihypertensive survival evaluation in Japan trial. Hypertension. 2008;51(2):393-398.

69. Kasanuki H, Hagiwara N, Hosoda S, et al. Angiotensin II receptor blocker-based vs non-angiotensin II receptor blocker-based therapy in patients with angiographically documented coronary artery disease and hypertension: the Heart Institute of Japan Candesartan Randomized Trial for Evaluation in Coronary Artery Disease (HIJ-CREATE). Eur Heart J. 2009;30(10):1203-1212.
70. Suzuki K, Nakagawa O, Aizawa Y. Improved early-phase insulin response after candesartan treatment in hypertensive patients with impaired glucose tolerance. Clin Exp Hypertens. 2008;30(5):309-314.

71. Bosh J, Yusuf S, Gerdtein H, et al. DREAM Trial Investigators Effect of ramipril on the incidence of diabetes. N Engl J Med. 2006;355(15): $1551-1562$.

72. Califf R, Boolell M, Hafner S, et al. NAVIGATOR Study Group. Prevention of diabetes and cardiovascular disease in patients with impaired glucose tolerance: rationale and design of the Nateglinide And Valsartan in Impaired Glucose Tolerance Outcomes Research (NAVIGATOR) Trial. Am Heart J. 2008;156(4):623-632.

73. Mitchell K, Braam B, Navar L. Hypertensiogenic mechanisms mediated by renal actions of rennin-angiotensin system. Hypertension. 1992;19 Suppl 1:I18-I27.

74. Lewis E, Hunsicker L, Bain R, Rohde R. The effect of angiotensinconverting-enzyme inhibition on diabetic nephropathy. The Collaborative Study Group. N Engl J Med. 1993;329(20):1456-1462.

75. Lovell H. Angiotensin converting enzyme inhibitors in normotensive diabetic patients with microalbuminuria. Cochrane Database Syst Rev. 2001;1:CD002183.

76. Strippoli G, Craig M, Craig J. Antihypertensive agents for preventing diabetic kidney disease. Cochrane Database Syst Rev. 2005;4:CD004136.

77. Lewis E, Hunsicker L, Clarke W, et al; Collaborative Study Group. Renoprotective effect of the angiotensin-receptor antagonist irbesartan in patients with nephropathy due to type 2 diabetes. $N$ Engl $\mathrm{J} \mathrm{Med}$. 2001;345(12):851-860.

78. Brenner B, Cooper M, Dezeeuw D, et al. RENAAL Study Investigators. Effects of losartan on renal and cardiovascular outcomes in patients with type 2 diabetes and nephropathy. $N$ Engl $J$ Med. 2001;345(12):861-869.

79. Parving H, Lehnert H, et al. Irbesartan in Patients with Type 2 Diabetes and Microalbuminuria Study Group. The effect of irbesartan on the development of diabetic nephropathy in patients with type 2 diabetes. N Engl J Med. 2001;345(12):870-878.

80. Stripolli G, Craig M, Deeks J, et al. Effects of angiotensin converting enzyme inhibitors and angiotensin II receptor antagonists on mortality and renal outcomes in diabetic nephropathy: systematic review. $B M J$. 2004;329(7470):828.

81. Mackenzie H, Troy J, Rennke H, Brenner B. TCV 116 prevents progressive renal injury in rats with extensive renal mass ablation. J Hypertens Suppl. 1994;12(9):S11-S16.

82. Kumagai H, Skata K, Matsuura T, et al. Comparison of ARB and ACEI for renoprotection in chronic glomerulonephritis. Nippon Rinsho. 2002;60(10):2005-2013.

83. Murayama S, Hirano T, Sakaue T, et al. Low-dose candesartan cilexetil prevents early kidney damage in type 2 diabetic patients with mildly elevated blood pressure. Hypertens Res. 2003;26(6):453-458.

84. Rossing K, Christensen P, Hansen B, et al. Optimal dose of candesartan for renoprotection in type 2 diabetic patients with nephropathy: a double-blind randomized cross-over study. Diabetes Care. 2003; 26(1):150-155.

85. Weinberg A, Zappe D, Ashton M, Weinberg M. Safety and tolerability of high-dose angiotensin receptor blocker therapy in patients with chronic kidney disease: a pilot study. Am J Nephrol. 2004;24(3):340-345.

86. Schmeider R, Klingbeil A, Fleischmann E, et al. Additional antiproteinuric effect of ultrahigh dose candesartan: a double-blind, randomized, prospective study. J Am Soc Nephrol. 2005;16(10):3038-3045.

87. Burgess E, Muirhead N, Decotret P, et al; the SMART (Supra Maximal Atacand Renal Trial) Investigators. Supramaximal dose of candesartan in proteinuric renal disease. J Am Soc Nephrol. 2009;20(4):893-900.

88. Kurokawa K, Abe K, Saruta T, et al. Antiproteinuric effect of candesartan cilexetil in patients with chronic glomerulonephritis. $J$ Renin Angiotensin Aldosterone Syst. 2002;3(3):167-175.

89. Omoto K, Tanabe K, Tokumoto K, et al. Use of candesartan cilexetil decreases proteinuria in renal transplant patients with chronic allograft dysfunction. Transplantation. 2003;76(8):1170-1174. 
90. Nutahara K, Higashihara E, Horie S, et al. Calcium channel blocker versus angiotensin II receptor blocker in autosomal dominant polycystic kidney disease. Nephron Clin Pract. 2005;99(1):c18-c23.

91. Mogensen C, Neldam S, Tikkanen I, et al; for the CALM Study Group. Randomised controlled trial of dual blockade of rennin - angiotensin system in patients with hypertension, microalbuminuria, and non-insulin dependent diabetes: the candesartan and lisinopril microalbuminuria (CALM)study. BMJ. 2000;321:1440-1444.

92. Kincaid-Smith P, Fairley K, Packham D. Dual blockade of the rennin-angiotensin system compared with a $50 \%$ increase in the dose of angiotensin-converting enzyme inhibitor: effects on proteinuria and blood pressure. Nephrol Dial Transplant. 2004;19(9):2272-2274.

93. Luno J, Barrio V, Goicoechea M, et al. Effects of dual blockade of the rennin-angiotensin system in primary proteinuric nephropathies. Kidney Int Suppl. 2002;82:S47-S52.

94. Rossing K, Christensen P, Jensen B, Parving H. Dual blockade of the rennin-angiotensin system in diabetic nephropathy: a randomized double-blind crossover study. Diabetes Care. 2002;25(1):95-100.
95. Andersen N, Poulsen P, Knudsen S, et al. Long-term dual blockade with candesartan and lisinopril in hypertensive patients with diabetes: the CALM II study. Diabetes Care. 2005;28(2):273-277.

96. Chatuverdi N, Porta M, Klein R, et al. DIRECT Programme Study Group. Effect of candesartan on prevention (DIRECT-Prevent 1) and progression (DIRECT-Protect 1) of retinopathy in type 1 diabetes: randomised, placebo-controlled trials. Lancet. 2008;372(9647):1394-1402.

97. Sjolie A, Klein R, Porta M, et al; DIRECT Programme Study Group. Effect of candesartan on progression and regression of retinopathy in type 2 diabetes (DIRECT-Protect 2): a randomised placebo-controlled trial. Lancet. 2008;372(9647):1385-1393.

98. De Rosa ML, Chiariello M. Candesartan improves maximal exercise capacity in hypertensives: results of a randomized placebo-controlled crossover trial. J Clin Hypertens. 2009;11(4):192-200.
Vascular Health and Risk Management

\section{Publish your work in this journal}

Vascular Health and Risk Management is an international, peerreviewed journal of therapeutics and risk management, focusing on concise rapid reporting of clinical studies on the processes involved in the maintenance of vascular health; the monitoring, prevention and treatment of vascular disease and its sequelae; and the involvement of

\section{Dovepress}

metabolic disorders, particularly diabetes. This journal is indexed on PubMed Central and MedLine. The manuscript management system is completely online and includes a very quick and fair peer-review system, which is all easy to use. Visit http://www.dovepress.com/ testimonials.php to read real quotes from published authors.

Submit your manuscript here: http://www.dovepress.com/vascular-health-and-risk-management-journal 